\title{
Influence of secondary packing on the freezing time of chiken meat in air blast freezing tunnels
}

\author{
Influência da embalagem secundária sobre o tempo de congelamento \\ de carne de frango em túneis de circulação de ar forçada
}

\section{Clarice de Ávila SANTOS ${ }^{1}$, João Borges LAURINDOํ, Vivaldo SILVEIRA JÚNIOR ${ }^{2}$, Haiko HENSE ${ }^{3 *}$}

\begin{abstract}
Freezing of poultry cuts in continuous convective air blast tunnels is normally performed with the products protected by Low Density Polyethylene (LDPE) as a primary packaging and using Corrugated Cardboard Boxes (CCB) as secondary packaging. The objective of this work was to investigate the influence of these secondary packaging on the freezing of poultry cuts in continuous convective air blast tunnels. The study was performed by replacing CCB with Perforated Metal Boxes (PMB) in order to remove the packaging thermal resistance. The assays, performed in a industrial plant, demonstrated that CCB used commercially for meat freezing have a high heat transfer resistance. Their replacement with PMB can lead to shorter freezing times and spatially homogeneous freezing. Reductions of up to $45 \%$ in the freezing times were observed using PMB. The plateau of the temperature curve, related to the freezing time of free water, was significantly reduced using PMB, which is accepted to lead to better product quality after thawing. As the products were protected by the LDPE films as primary packaging, their appearance were not affected. The results presented in this work indicate that replacing CBB with PMB can be an excellent alternative to reduce freezing time and improve freezing homogeneity in industrial air blast tunnels, which could also be applied to other products.
\end{abstract}

Keywords: chicken meat; freezing time; air blast tunnels; secondary packaging.

\section{Resumo}

O congelamento de cortes de frango em túneis convectivos é normalmente realizado com o produto envolto por filmes de polietileno de baixa densidade (PEBD, embalagem primária) e acondicionado em caixas de papelão ( $\mathrm{CP}$, embalagem secundária). O objetivo deste trabalho foi avaliar o efeito da embalagem secundária no congelamento dos cortes de frango. Para isso, compararam-se as curvas de congelamento do produto processado acondicionado em caixas metálicas perfuradas (CMP), que praticamente eliminam a resistência térmica da embalagem secundária, com as curvas de congelamento do produto nas CP. Os ensaios, realizados em uma planta industrial de processamento de aves, indicaram que as CP possuem uma grande resistência térmica e que a substituição delas por PMB pode resultar em maior homogeneidade espacial do processo de congelamento e em tempos de processo $45 \%$ inferiores. A duração do patamar de temperaturas que caracteriza a etapa de solidificação foi sensivelmente reduzida, o que favorece a obtenção de produtos congelados de melhor qualidade. A aparência dos produtos congelados em CMP não foi afetada, devido à proteção oferecida pelo PEBD. Assim, a substituição das caixas de papelão por caixas metálicas perfuradas pode ser uma excelente alternativa para reduzir o tempo de congelamento e melhorar sua homogeneidade espacial em túneis industriais.

Palavras-chave: cortes de frango; tempo de congelamento; túneis convectivos; embalagem secundária.

\section{Introduction}

Freezing provides food conservation for long time, maintaining most of its original characteristics. Food freezing is a phase change heat transfer problem, with consequent changes in its thermophysical properties during the conversion of water into ice. These phenomena do not happen at a constant temperature, but over a temperature range depending on the food composition and structure, its physical geometry, initial freezing temperature, and operational conditions (ASHRAE, 1998).

Meat products have complex composition and the freezing conditions can influence considerably the water losses during thawing, with consequent quality changes. During slow freezing, ice crystals grow results in concentration of solutes in the extra cellular spaces, allowing water migration through the cellular membrane due to osmotic effects. If thawing is not performed very slowly, the water cannot be totally reabsorbed, leading to product exudation. The exudates contains sensorial and nutritional components, and influences product softness and juiciness.

Shorter freezing times (time from the beginning of chilling up to the final temperature of $-18^{\circ} \mathrm{C}$ in the food center) lead

Recebido para publicação em 8/8/2007

Aceito para publicação em 14/7/2008 (002744)

${ }^{1}$ Departamento Engenharia Química e Alimentos, Universidade Federal Santa Catarina - UFSC, CEP 88040-900, Florianópolis - SC, Brasil

${ }^{2}$ Departamento Engenharia de Alimentos, Universidade Estadual de Campinas - UNICAMP, CEP 13083-862, Campinas - SP, Brasil

${ }^{3}$ Laboratório de Termodinâmica e Extração Supercrítica - LATESC, Departamento de Engenharia Química e Engenharia de Alimentos - EQA,

Universidade Federal de Santa Catarina - UFSC, CEP 88040-900, Florianópolis - SC, Brasil, E-mail: h_hense@enq.ufsc.br

${ }^{*}$ A quem a correspondencia deve ser enviada 
to smaller ice crystals and lower water losses during thawing (BRENNAN, 1980; PARDI et al., 2001; SINGH, 1977). Poultry and other meat products are generally frozen in forced air blast tunnels where the circulating air flows at 3 to $8 \mathrm{~m} / \mathrm{s}$, at temperatures ranging from -35 to $-45^{\circ} \mathrm{C}$. Those freezing tunnels present diverse geometries and air flow heterogeneities (SANTOS et al., 2007), but the heat transfer from the product to the air takes place always in transient state (PARDI et al., 2001; RESENDE et al., 2002a).

On the other hand, to avoid superficial drying and pale appearance of the frozen meats, these products have to be protected by low permeability plastic films, e.g., low density polyethylene (LAWRIE, 1985). To avoid mechanical damage of the products during freezing, it is also necessary a secondary packaging, strong enough to support the transport of the products through the tunnel (ASHRAE, 1998; SILVA, 2000). Moreover, packaging material with low thermal resistance would be of interest. Due to the complexity of the interfaces between the product and the primary packaging, the gap between the primary and secondary packaging as well as the thermal contact resistances, it is difficult to decompose the different resistances to heat transfer quantitatively during freezing.

The objective of this work was to verify the influence of commercial secondary packaging $(\mathrm{CCB})$ in the freezing time of poultry cuts wrapped in PEBD films in continuous convective air blast tunnels. This study was performed by replacing Commercial Cardboard Boxes (CCB) with Perforated Metal Boxes (PMB).

\section{Materials and methods}

\subsection{Samples of chicken meat and the primary packaging}

Chicken wings weighing between 80 and 120 g were used in all experiments. These wings were arranged in two layers inside the corrugated cardboard box resulting in approximately $15 \mathrm{~kg}$ of the product. The layers were separated by a LDPE film with thickness of $0.6 \mathrm{~mm}$, considered here as the primary packaging. Moreover, each box had a LDPE film of $0.3 \mathrm{~mm}$ placed into the inner side (bottom and lateral walls), preventing the product to have contact with the surrounding air.

\subsection{Corrugated cardboard box (CCB)}

Corrugated Cardboard Boxes (CCB) had dimensions of $570 \times 365 \times 100 \mathrm{~mm}$. These boxes were introduced into the freezing tunnel without the top cover to allow better heat transfer from the product to the air. A scheme of the product inside the package and its characteristic dimensions is shown in Figure 1a.

\subsection{Perforated metal boxes (PMB)}

The Perforated Metal Boxes (PMB) were manufactured specially for the tests (Figure 1b) having the same dimensions as the cardboard boxes to allow comparisons. Each hole of the plate had $20 \mathrm{~mm}$ diameter resulting in a $81 \%$ perforated surface, which is high enough to allow an efficient contact between air and food (VIGNEAULT et al., 2004a; VIGNEAULT

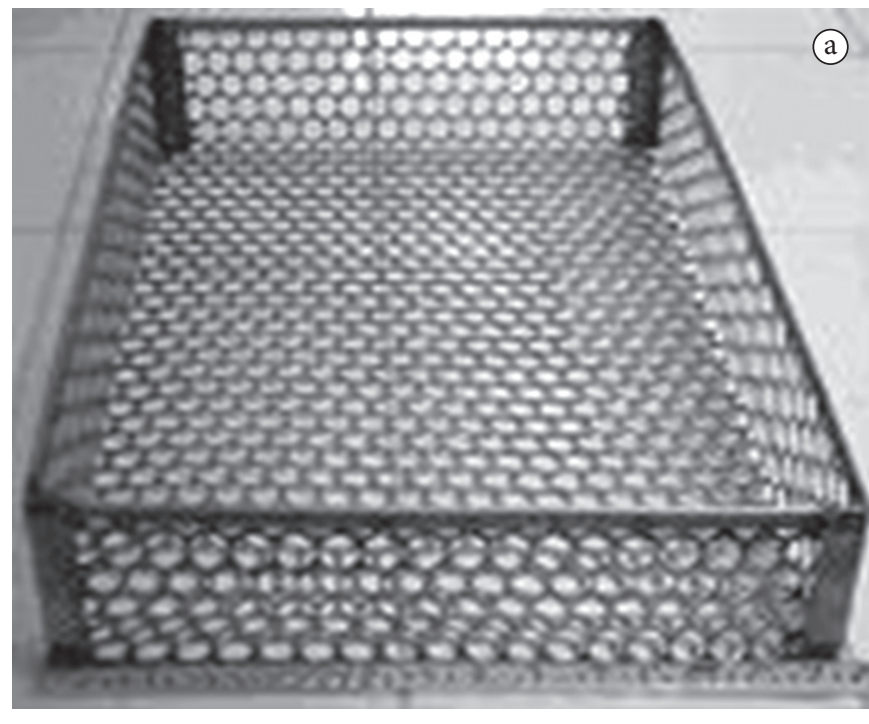

(b)

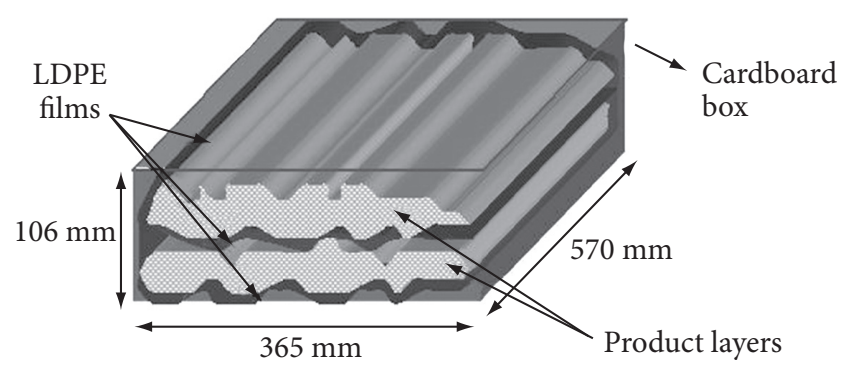

Figure 1.a) Diagram of the product packaging, with polyethylene film layers; and b) Photograph of a perforated metal box.

et al., 2004b). As PMB presented almost no thermal resistance between the primary packaging and cold air, the secondary packaging thermal resistance was practically eliminated.

\subsection{Temperature recording}

Pt-100 sensors provided with data logger (Type Temprecord International Limited, model Multi-Trip, New Zeeland) were used for the measurement and recording of products timetemperature evolutions. Those instruments were programmed to collect and record temperatures in time intervals of two minutes. To perform the measurements, sensors were inserted and fixed in the geometric center of the product box. Recorded temperature data were loaded into a PC through a dedicated interface with the data logger software.

\subsection{Freezing tunnels}

The product freezing was monitored in two continuous tunnels with different capacities, quantity and location of fans and operating mode.

\section{Automatic freezing tunnel 1 (AFT1)}

This tunnel had 10 levels, each one with height of $0.200 \mathrm{~m}$, in which the product boxes were transported by a transport belt. The 
boxes were placed very close to each other, not allowing air circulation around them. The product transport during the freezing process occurred only horizontally, in the normal air flow direction. The AFT1 had 35 fans placed in the same side, as shown in Figure 2a. The fans had a diameter of $0.9 \mathrm{~m}$ and power of $2237 \mathrm{~W}$ (total of $78.3 \times 10^{4} \mathrm{~W}$ ). Cold air flux occurred perpendicularly to the product movement, above and below the boxes, but not around them, due to the boxes arrangement. The global evaporator's area is $6000 \mathrm{~m}^{2}$, distributed at the top side of the tunnel in ten blocks. The air temperature inside the tunnel was $-38^{\circ} \mathrm{C}$ and the product residence time was approximately 13.8 hours.

\section{Automatic freezing tunnel 2 (AFT2)}

The AFT2 was constituted of 14 levels, with height of $0.230 \mathrm{~m}$. In each level 15 boxes were placed, very close to each other. The product transport during the freezing process occurred only horizontally, in counter current with the cold air. This flow differs from the AFT1's, in which the air flow was perpendicular to the products. The AFT2 had 9 fans placed on the back of the tunnel, close to the product exit, as shown in Figure 2b. Those fans had $1200 \mathrm{~mm}$ diameter and power of $7460 \mathrm{~W}(10 \mathrm{HP})$, totalizing $4113 \mathrm{~W}(90 \mathrm{HP})$ power. The total
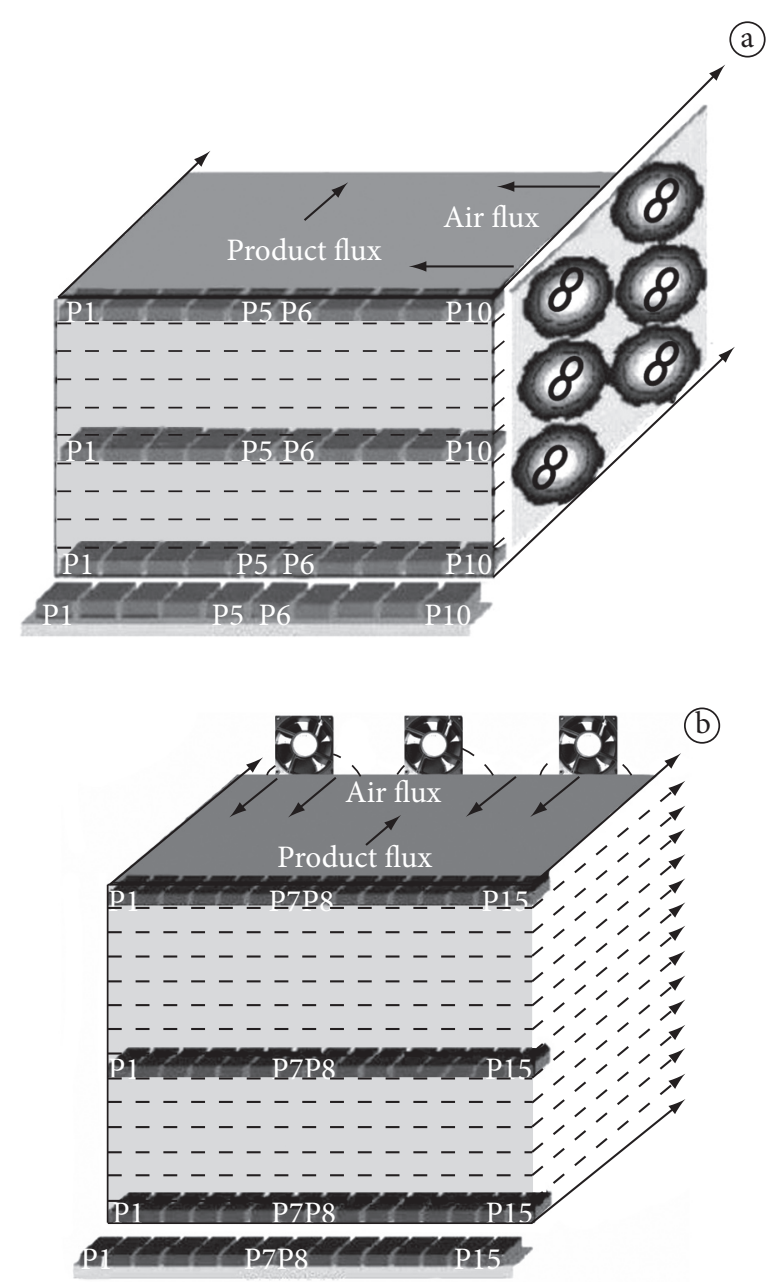

Figure 2. Schematic diagrams illustrating the fan positions, the flow directions of cold air and the product, and the product box positions in the tunnel levels for a) AFT1; and b) AFT2. area of the evaporators was $9324 \mathrm{~m}^{2}$, located at the upper back of the tunnel, occupying the air return space. The tunnel air temperature was $-38{ }^{\circ} \mathrm{C}$ and the product residence time was approximately 15.6 hours.

\subsection{Time-temperature evolution during freezing}

To perform the tests, temperature sensors were inserted and fixed in the geometric center of the products in the PMB. The sensors and $\mathrm{PMB}$ used in the tests were labeled and programmed for measuring temperature every 2 minutes. Each PMB had its dimensions and weight registered for control. The mass of the product inside each $\mathrm{PMB}$, for each assay, was also determined. Besides, the same procedure was used to investigate the freezing of three CCBs, in order to compare the time-temperature evolution of the product in the two different "packagings". At the end of the freezing process (in the tunnel exit), the temperature sensors were withdrawn and connected into a PC to load the time-temperature data of PMB and CCB.

In the AFT1, the tests were performed to compare freezing times of CCB and PMB for every tunnel level, changing boxes positions in relation to the fans. At the bottom of the tunnel, three positions were compared: position 1 (P1) far from the fans, intermediate position (P5 or P6), and position 10 (P10), position closest to the fans. Product residence time in AFT1 was close to 13.8 hours. Those tests were repeated to observe reproducibility. The same procedure was repeated for the AFT2.

\subsection{Thermal resistance of $C C B$}

Freezing times of products conditioned in CCB and in PMB were compared. The PMB holes led to drastic reduction of the thermal resistance, because cold air had direct contact with the primary packaging (LDPE film). Moreover, the thermal conductivity of the steel is relatively high $\left(\mathrm{K}_{\text {steel }}=13.8 \mathrm{~W} / \mathrm{m}^{\circ} \mathrm{C}\right.$ at $0{ }^{\circ} \mathrm{C}$, GEANKOPLIS, 1993). The time-temperature evolution at the product's geometric center was analyzed for the two situations. Hence, the resistance to heat transfer offered by the cardboard box was assessed.

The evaluation of the global thermal resistance offered by the CCB containing the product is important to discriminate the contribution of the different thermal resistances between the product and cold air. This is shown in Figure 3. The thermal resistance $\mathrm{R}_{1}$ is related to the convective heat transfer between CCB and air and $A$ is the heat transfer area. $R_{1}$ can vary according to the box position in the tunnel (different values of the convective heat transfer coefficient (h) due to the heterogeneity of air velocity). The resistance $R_{2}$ is the conductive thermal resistance related to the thickness $L_{2}$ of the box wall. The resistance $R_{3}$ is the resistance which involves physical contact between the CCB and LDPE film and between the film and the product. The $\mathrm{R}_{3}$ value is also influenced by the thermal resistance offered by the air present between the product and the primary packaging and between the latter and the CCB wall. $T_{A}$ and $T_{B}$ are the superficial contact temperatures and $\mathrm{q}_{\mathrm{x}}=\mathrm{T}_{\mathrm{A}}-\mathrm{T}_{\mathrm{B}} / \mathrm{R}_{3} \cdot \mathrm{R}_{3}$ is difficult to measure experimentally. The $\mathrm{R}_{4}$ resistance is related to the ensemble formed by the product (peel, meat and bone) and LDPE film. 


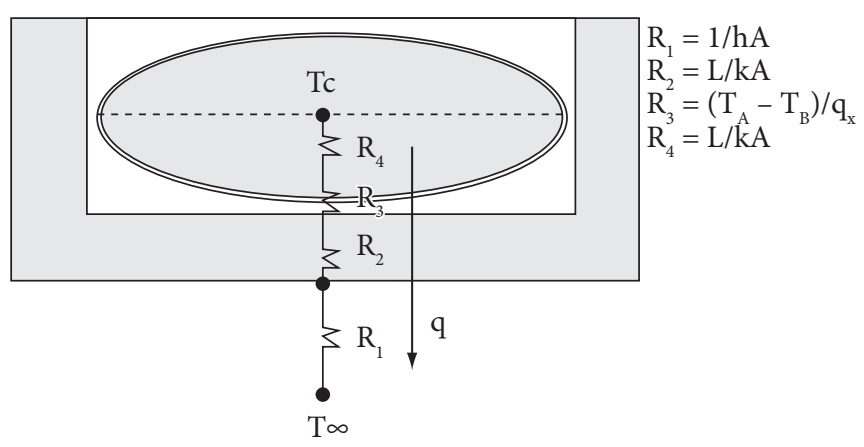

Figure 3. Thermal resistances involved in the product freezing, where $\mathrm{R}_{1}$ is related to the convective heat transfer between product and the air; $A$ is the heat transfer area; $R_{2}$ is related to the length $L$ of the CCB. Resistance $\mathrm{R}_{3}$ is the contact resistance for the contact between the box and film and between the film and product. Resistance $R_{4}$ is related to the product containing skin, bone, and meat and to the LDPE films.

It can be verified that the freezing of packaged foods is a complex heat transfer problem. Furthermore, product thermophysical properties are difficult to measure due to the presence of peel, bones, fat and meat, and because they undergo big changes around the freezing point (HELDMAN, 1992; RESENDE; SILVEIRA JUNIOR, 2002). Thus, the effect of $\mathrm{R}_{2}$ was evaluated indirectly through the comparison between the product freezing times in the two kinds of boxes submitted to identical freezing conditions.

The temperature of $-18^{\circ} \mathrm{C}$ at the product center was chosen as the maximal temperature allowed for the product after freezing because at this temperature more than $85 \%$ of the water is frozen, reducing drastically undesirable changes (ASHRAE, 1998; EVANGELISTA, 1989; PARDI et al., 2001).

\section{Results and discussion}

The results of the product freezing with the two secondary packagings are presented according to the freezing tunnel used in the tests.

\subsection{Automatic freezing tunnel 1 (AFT1)}

Representative results of experiments performed in AFT1 are shown in Figures 4a and $4 \mathrm{~b}$ for the lower level, in Figures $4 \mathrm{c}$ to $4 \mathrm{f}$ for the intermediate level, and in Figures $4 \mathrm{~g}$ and $4 \mathrm{~h}$ for the upper level. For the lower level, it was found that even in the position next to the fans the product freezing time in the PMB was reduced by almost $45 \%$ when compared with the product in the $\mathrm{CCB}$ boxes. In some cases, product freezing times in the PMB were almost $70 \%$ shorter than in the CCB boxes. At the tunnel intermediate level, three different positions were compared, as shown in Figures 4c to $4 \mathrm{f}$. Freezing time reductions of around $40 \%$ were observed for the PMB in the three positions at this level. For the upper level, some boxes were placed close to the fans $\left(\mathrm{P}_{10}\right)$ and others at some distance from them $\left(\mathrm{P}_{1}\right)$. By comparing the freezing times and the temperature variations of $\mathrm{PMB}$ and $\mathrm{CCB}$, a reduction in the freezing time of up to $42 \%$ for the position close to the fans, as shown in Figures $4 \mathrm{~g}$ and $4 \mathrm{~h}$, was found.
In summary, in all cases, product freezing time (time to reach temperatures of $-18{ }^{\circ} \mathrm{C}$ in product center) was reduced by more than $40 \%$ by replacing CCB with PMB.

\subsection{Automatic freezing tunnel 2 (AFT2)}

Like for AFT1, the aim of the tests performed in ATF2 was to compare product freezing times using $\mathrm{PMB}$ and $\mathrm{CCB}$. Two different positions in the lowest tunnel level $\left(\mathrm{N}_{1}\right)$ were also compared. In this case, the positions referred to the sequence in which the boxes entered the tunnel, because all boxes moved in counter flow with the cold air flow. If the air distribution in AFT2 were homogeneous, the location of the boxes would not influence the freezing time. Figures $5 \mathrm{a}$ and $5 \mathrm{~b}$ show the results for the lowest level $\mathrm{N}_{1}$. In the tests performed in AFT2, the final temperature of the product packaged in CCB did not reach $-18^{\circ} \mathrm{C}$. Small extrapolations of the freezing curves indicated that the freezing time can be reduced by around 5 hours, as illustrated by Figure 5a, and by around 3 hours, as shown in Figure 5b. The product residence time in the tunnel was maintained at 15.6 hours, which is consistent with the normal operational conditions of the tunnel. The results shown in Figures $5 \mathrm{a}$ and $5 \mathrm{~b}$ indicate that the product temperature in the $\mathrm{PMB}$ did not reach the critical temperature of $-18^{\circ} \mathrm{C}$ during the test. Other similar tests were carried out in the central positions of AFT2, and they confirmed the results observed in the other positions. Results of more than thirty tests carried out in the continuous tunnels 1 and 2 demonstrated that the reduction in the freezing time of up to $45 \%$ can be obtained using PMB as the secondary packaging. In some tests the time saved was greater than 5 hours. With this data and considering that PMB offer a quasi-null resistance, it is possible to verify the influence of the CCB on the heat transfer resistance. Another important result was the reduction in the duration of the temperature plateau using PMB. As the duration of this plateau is directly related to the size of ice crystals, less damage will be caused to the muscular tissue of the meat using PMB during freezing (BRENNAN et al., 1980).

It was also observed that the use of CCB minimized the differences in the freezing time of the products placed at different tunnel positions caused by non-homogeneous air velocity inside the tunnel. Figure 6 shows the comparison of the product freezing times at different levels (N1, N6 and N10) but at the same position (intermediary position P6) in the AFT1. Utilizing CCB, the freezing times were 11 and 12.8 hours (difference of 1.8 hours), respectively, whereas using PMB this difference was reduced to 0.6 hours (6.4 to 7 hours freezing time) in the same positions.

All results obtained confirmed that the use of PMB during food freezing can provide qualitative and quantitative benefits to the freezing operation. If the PMB are built with the same dimensions as the CCB, it will allow their perfect movement through the tunnels. Further research is necessary to implement the use of PMB in factories because frozen products need to be transferred to CCB before distribution. Their implementation should be evaluated for every case, but this will be not discussed in this study. 

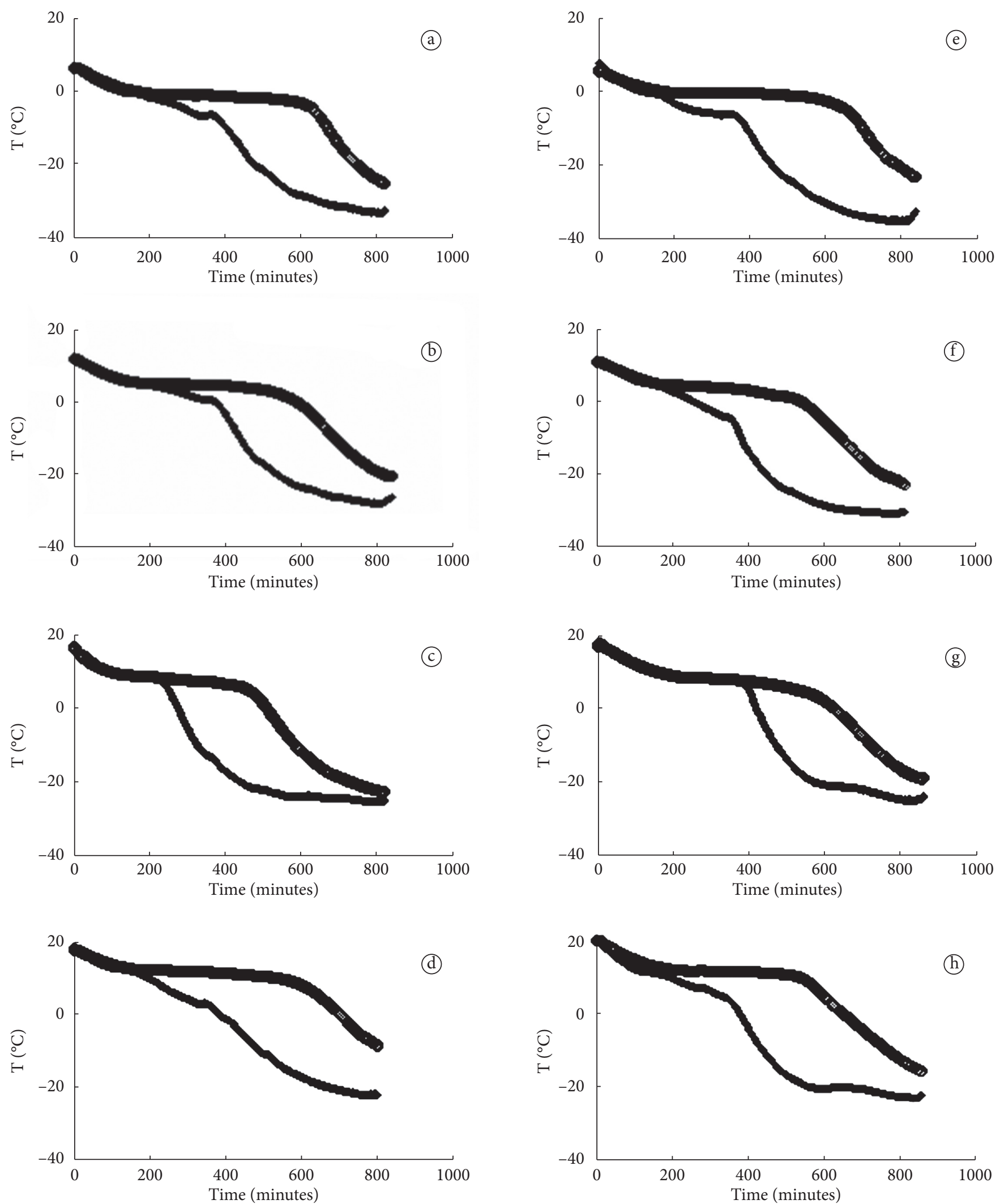

Figure 4. Cooling and freezing curves for the product in $\mathrm{CCB}$ and PMB in AFT1 at the bottom of the tunnel: a) position far from the fans; b) intermediary position; c) position next to the fans; at the intermediate level: d) position far from the fans; e) intermediate position; f) position next to the fans; and at the upper level: g) position far from the fans; h) position next to the fans. 

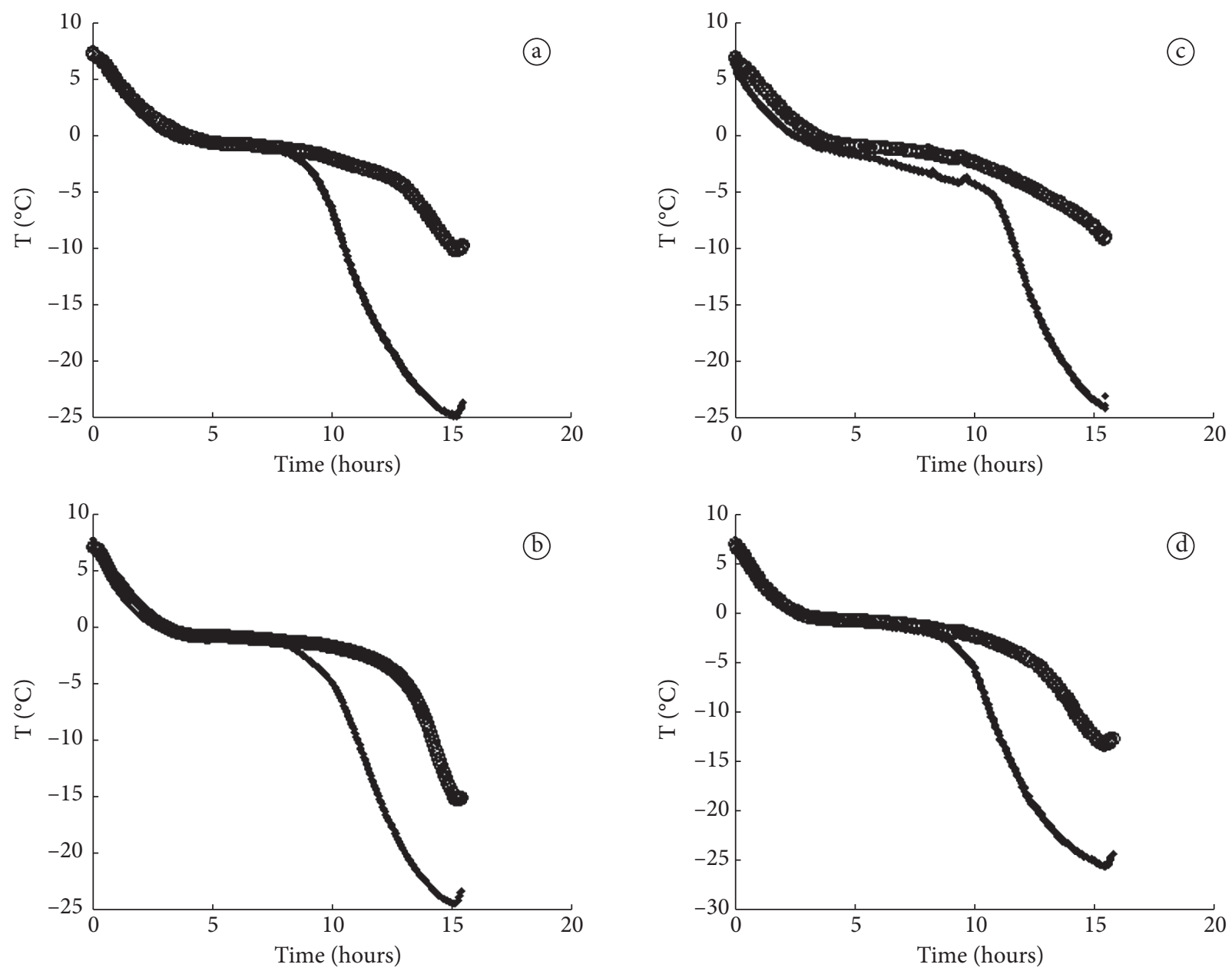

Figure 5. Cooling and freezing curves for the product in CCB and PMB in AFT2 at the bottom of the tunnel: a) position of the first box; b) position of the last box; and at the upper level: c) position of the first box; d) position of the last box.

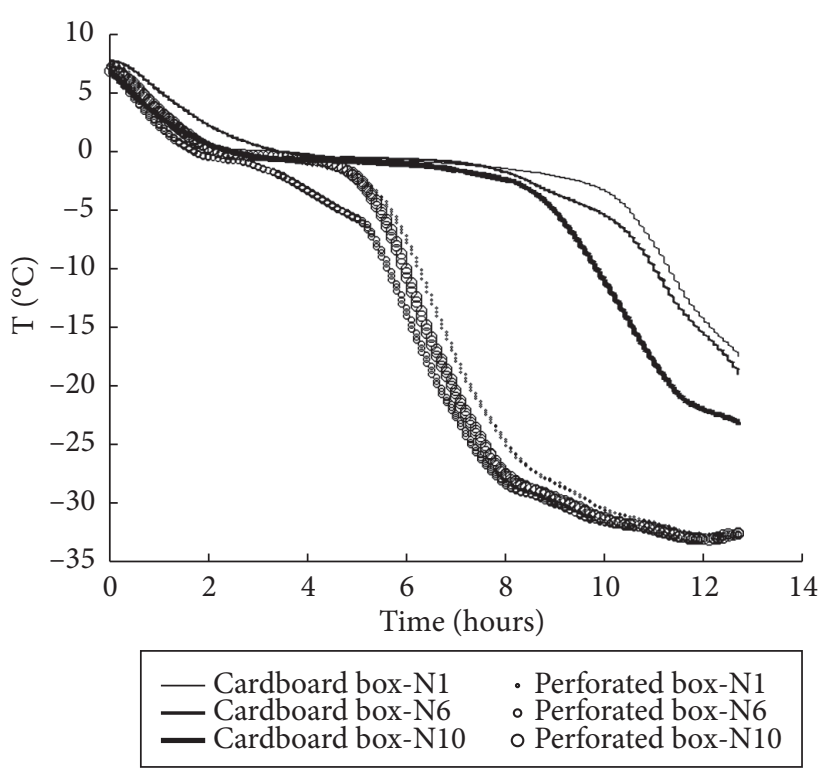

Figure 6. Comparison between the cooling and freezing curves obtained from the freezing of the product in $\mathrm{CCB}$ and $\mathrm{PMB}$ and the influence of spatial distribution on freezing times in AFT1.

\section{Conclusions}

The tests carried out demonstrated empirically that cardboard boxes used commercially as secondary packaging for meat freezing have a high heat transfer resistance. The results presented in this work indicate that replacing $\mathrm{CBB}$ with $\mathrm{PMB}$ can be an excellent alternative to reduce freezing time and improve freezing homogeneity in industrial air blast tunnels, which could also be applied to other products. Reductions of up to $45 \%$ in the freezing times can be achieved using PMB. The plateau of the temperature curve characterizing solidification was significantly reduced using $\mathrm{PMB}$, which can result in better product quality. Moreover, the use of PMB reduces heterogeneities in the temperature of frozen products.

The tests were performed with chicken meat, but they may be applied to the freezing of other foods.

\section{References}

ASHRAE - American Society of Heating and Air-Conditioning Engineers. Refrigeration Handbook, Food Storage and Equipment, Food Refrigeration. Atlanta, 1998. 
BRENNAN, J. G. et al. Las Operaciones de la ingenieria de los alimentos. 2 ed. Zaragoza, Espanha: Acribia, 1980. p. 367-377.

LAWRIE, R. A. Meat Science. 4 ed. New York: Pergamon Press, 1985. p. $112-134$.

PARDI, M. C. et al. Ciência, higiene e tecnologia da carne. 2 ed. Goiânia: UFG, 2001. v. 1.

RESENDE, J. V.; NEVES FILHO, L. C.; SILVEIRA JUNIOR, V. Escoamento de ar através de embalagens de polpa de frutas em caixas comerciais: efeito sobre os perfis de velocidade em túneis de congelamento. Ciência e Tecnologia de Alimentos, v. 22, n. 2, p. 184-191, maio/ago. 2002.

RESENDE, J. V.; SILVEIRA JUNIOR, V. Medidas da condutividade térmica efetiva de modelos de polpas de frutas no estado congelado. Ciência e Tecnologia de Alimentos, v. 22, n. 2, p. 177-183, maio/ ago. 2002.
SANTOS, C. A. et al. Determination of heat transfer coefficient in cooling-freezing tunnels using experimental time temperature data. Journal of Food Process Engineering, v. 30, n. 6, p. 1-12, 2007.

SILVA, J. A. Tópicos da Tecnologia de Alimentos. São Paulo: Livraria Varela, 2000. p. 147-159.

SINGH, R. P.; HELDMAN, D. R. Introduccion a la ingenieria de los alimentos. Zaragoza, Espanha: Acribia, 1977.

VIGNEAULT, C. et al. Indirect airflow measurement for horticultural crop package. Part II: Verification of the research tool applicability. In: ASAE Annual International Meeting, 2004a. p. 7331-7344.

VIGNEAULT, C.; CASTRO, L. R.; GAUTRON, G. Effect of open handles on packages during precooling process of horticultural produce. In: ASAE Annual International Meeting, 2004b. p. 6901-6908. 